Article

\title{
Ecological and Economic Benefits of the "Medium" Level of the Building Thermo-Modernization: A Case Study in Poland
}

\author{
Janusz Adamczyk ${ }^{1}$ a and Robert Dylewski ${ }^{2, *(1)}$ \\ 1 Faculty of Economics and Management, University of Zielona Góra, ul. Licealna 9, 65-417 Zielona Góra, \\ Poland; J.Adamczyk@wez.uz.zgora.pl \\ 2 Faculty of Mathematics, Computer Science and Econometrics, Institute of Mathematics, University of \\ Zielona Góra, ul. Licealna 9, 65-417 Zielona Góra, Poland \\ * Correspondence: R.Dylewski@wmie.uz.zgora.pl; Tel.: +48-6832-82821
}

Received: 14 July 2020; Accepted: 20 August 2020; Published: 1 September 2020

\begin{abstract}
Energy saving is at the heart of sustainable development in the context of climate change. Saving energy is not only the amount of energy that we save, but also reducing emissions of pollutants to the atmosphere, as well as reducing the consumption of energy resources that are used to produce energy. Reducing pollutant emissions and the use of energy resources can be achieved by increasing the use of renewable energy sources, but at present, this method of obtaining energy in the world is not representative. It should be noted that renewable energy devices throughout the life cycle generate environmental impact. Similar to this situation, the building's thermo-modernization, which is focused on reducing the pressure on the environment of the building's user, also has an impact on the environment throughout the building's life cycle. Determining this environmental impact and ecological or economic benefits or costs is the purpose of the following article. Thermo-modernization of the building, for the purposes of the article, is understood as thermal insulation of walls and replacement of the heat source for heating the building and preparation of hot utility water. The need to replace the heat source with a much more ecological one results in Poland from provincial legal regulations announced by virtue of a resolution. In the study, data from the Ecoinvent data library included in the SimaPro computer program was used for the LCA (Life Cycle Assessment) analysis. As a result of thermo-modernization of the representative buildings, large ecological benefits were obtained, while economic costs remain at a high level.
\end{abstract}

Keywords: thermal energy; thermo-modernization; thermal insulation; heat source replacement; ecological and economic benefits; life cycle assessment

\section{Introduction and Literature Review}

Thermo-modernization is a broad concept, often mistakenly associated only with thermal insulation of building walls. It also includes the replacement of heat sources with much more ecological, often with higher efficiency, replacement of windows or modernization of heating systems. The thermo-modernization project, in accordance with the Act on supporting thermo-modernization and renovation [1], is an "[improvement] as a result of which the annual energy demand for heating and heating of utility water is reduced by 10 to $25 \%$, depending on the type of modernization and previous improvements". Firlag [2] and BPIE, Staniaszek and Firlag [3] distinguish three levels of thermo-modernization in Poland and assign thermo-modernization projects to each level: 
1. "Low"-modernization or replacement of heat source.

2. "Medium"-modernization or replacement of heat source together with: Replacement of window and door joinery or thermal insulation of a façade.

3. "Deep"-total or partial replacement energy sources, the use of renewables or the use of high-efficiency cogeneration; replacement of the central heating and DHW with insulation (in accordance with current technical and construction regulations); replacement of external window and door joinery; insulation of the whole external envelope (façades, flat roof and the ceiling/floor); repair of balconies.

The authors draw attention to the fact that at the "low" level there is a reduction of final energy within $0-30 \%$, for the "medium" level 30-60\% and for the "deep" level 60-90\% [3]. There is no direct relationship between the terminology used in the European Directives and the terminology used in BPIE-Financing building energy performance improvement in Poland (the terminology used in the article).

Szulc and Kokoszka [4] determined the energy characteristics of the studied buildings based on the actual energy consumption for heating. Calculations were made for the state before and after thermo-modernization. The collected variables were used to build a prognostic model based on fuzzy set theory. The use of this method makes it possible to accurately determine the energy-saving potential for heating after thermo-modernization. The model developed on the basis of the fuzzy set theory turned out to be a universal solution [4].

Rønneseth and others [5] evaluated the possibility of reducing the supply temperature in existing Norwegian apartment blocks by improving the thermal envelope and lowering the temperature levels in the heating system. On the basis of a heating set point of $22{ }^{\circ} \mathrm{C}$ and a minimum permissible indoor temperature of $19{ }^{\circ} \mathrm{C}$, in accordance with Norwegian building regulations, they concluded that it should be possible to reduce the radiator supply temperature from 80 to $60{ }^{\circ} \mathrm{C}$ for apartment blocks newer than 1970. For older buildings, simulations showed that an improvement in energy efficiency corresponding to "indirect renovation" (indirect renovation involves the replacement of window woodwork with a modern one with a lower heat transfer coefficient) is necessary before the supply temperature is lowered, in order to keep the indoor temperature above $19^{\circ} \mathrm{C}$. Because residents may experience thermal discomfort at $19^{\circ} \mathrm{C}$, the authors recommend standard renovation to ensure users' satisfaction and improve efficiency energy of buildings.

Zender-Swiercza and Telejko [6] draw attention to significant changes that are taking place in the existing building as a result of thermo-modernization projects. They noticed that in buildings where the change consisted only of applying a layer of thermal insulation on the wall or ceiling, the quality of air deteriorated. The amount of air flowing through the building was reduced, as a result of which air quality deteriorated and mould appeared on building walls. The authors suggest improving air quality by choosing another insulation material (allowing air diffusion) or using mechanical or hybrid ventilation.

Woroniak and Piotrowska-Woroniak [7] describe how to thermo-modernize churches to improve energy efficiency, and proposed changes in the heating system and heat source. Five churches were analyzed for thermo-modernization. Replacement of the existing heat source with a biomass-fired boiler was proposed in three churches. In one of the next churches, it was proposed to replace it with a fuel-fired boiler, while in the "fifth" church, due to the good condition of the coal boiler, its replacement was not planned. In each church building, after carrying out thermo-modernization projects, the authors determined energy benefits. Churches cannot be compared to typical residential buildings, but the authors of this work proposed to improve the energy efficiency of these buildings, taking into account the law of monument protection.

A large part of the articles refers to the methodology that determines the optimal thickness of thermal insulation in economic and environmental terms [8-13]. The authors using various methodologies demonstrate economically and (in some cases) ecologically conditioned optimal insulation thickness. 
In Poland, the big problem is individual boiler houses for single-family houses. Over $60 \%$ of multi-family buildings use the municipal heating network. The remaining ones mostly use ecological heat sources. It should be observed that there is a scientific space that has not yet been included in scientific articles regarding the evaluation of the economic and ecological benefits of thermal insulation of vertical building walls in connection with the replacement of the heating medium, which corresponds to the level of "medium" modernization of the building. Section 3 proposes the use of LCA (Life Cycle Assessment), and Sections 5.1 and 6.1 introduce a methodology for the ecological and economic assessment of this type of thermo-modernization.

\section{Characteristics of Legal Requirements in Poland Regarding the Use of Solid Fuel Boilers}

The territorial division of Poland is three stages: The first level units are voivodships. There are 16 voivodships in Poland. Since 2015 in Poland, pursuant to the amended Environmental Protection Law (Article 96 (1)), the voivodship parliament may, by way of resolution, introduce restrictions or prohibitions on the operation of installations in which fuel is burnt. Nine voivodships in Poland (as of 2 May 2020) introduced, pursuant to a resolution, legal provisions introducing a gradual elimination from the use of solid-fuel boilers less than 5 class with the PN EN 303-5:2012 standard [14] from 1 January 2022 to 1 January 2028. Each of the voivodships introduces separate provisions that are implemented at different time intervals; however, the final time of completion of these changes is identical for all voivodships and falls on 1 January 2028.

It should also be mentioned that from 1 October 2017, boilers that do not meet the class 5 emission standards in accordance with PN EN 303-5:2012 [14] are banned throughout Poland. Boilers that were produced before this date could still be sold until 30 June 2018.

In Poland, in 2018, 65.3\% of solid fuels were used for central heating (municipal heating plants and individual boiler rooms) (of which 57.5 were coal and coke, 4.5 forest biomass and $3.3 \%$ other solid fuels from biomass), $32.8 \%$ gas fuels and $1.9 \%$ liquid fuels [15].

Table 1 presents the share of households (individual boiler rooms) only using individual energy carriers for space heating. Comparing individual years (especially 2015 to 2018), it can be noticed that there is a downward trend in the use of solid fuels, especially when it comes to the use of brown coal, coke, firewood and other types of biomass. The use of hard coal in Poland remains unchanged.

Table 1. Share of households using individual energy carriers for space heating in Poland [\%].

\begin{tabular}{ccccc}
\hline Source of Energy & $\mathbf{2 0 0 9}$ & $\mathbf{2 0 1 2}$ & $\mathbf{2 0 1 5}$ & $\mathbf{2 0 1 8}$ \\
\hline Electricity & 4.57 & 3.76 & 3.12 & 3.97 \\
\hline Heat from the municipal network & 26.7 & 28.88 & 28.91 & 31.41 \\
\hline Natural gas & 6.10 & 6.12 & 7.00 & 10.89 \\
\hline Liquid gas (propane-butane) & 0.26 & 0.21 & 0.21 & 0.39 \\
\hline Heating oil & 0.33 & 0.28 & 0.28 & 0.39 \\
\hline Coal & $\mathbf{2 8 . 3 4}$ & $\mathbf{2 8 . 3 9}$ & $\mathbf{2 8 . 0 1}$ & $\mathbf{2 8 . 3 8}$ \\
\hline Lignite & $\mathbf{0 . 8 0}$ & $\mathbf{0 . 9 7}$ & $\mathbf{0 . 7 6}$ & $\mathbf{0 . 3 9}$ \\
\hline Coke & $\mathbf{0 . 5 3}$ & $\mathbf{0 . 4 9}$ & $\mathbf{0 . 5 5}$ & $\mathbf{0 . 4 7}$ \\
\hline Firewood & $\mathbf{2 8 . 2 1}$ & $\mathbf{2 7 . 8 3}$ & $\mathbf{2 8 . 9 1}$ & $\mathbf{2 2 . 3 9}$ \\
\hline Other types of biomass & $\mathbf{4 . 1 1}$ & $\mathbf{2 . 9 9}$ & $\mathbf{2 . 0 9}$ & $\mathbf{1 . 0 1}$ \\
\hline Solar energy & 0.03 & 0.05 & 0.11 & 0.10 \\
\hline Heat pump & 0.02 & 0.03 & 0.05 & 0.21 \\
\hline
\end{tabular}


It should also be added that over $20 \%$ of operated solid-fuel boilers are heating devices whose age is 20 years and more [17]. Due to the scale of the phenomenon (in Poland, about $50 \%$ of households use boilers for solid fuels for heating $[16,18]$ the process of replacing old boilers with pro-ecological ones is a big economic challenge, but from an environmental point of view, it can have great benefits. The concept of determining these benefits is presented in the next part of the article.

\section{Methodology of LCA Analysis}

LCA analysis is a technique often used in the study of various fields of science relating to the estimation of environmental aspects. It is described in the ISO 14,040 and ISO 14,044 standards, which set specific methodological requirements for those conducting the analysis [19,20]. According to these norms, the correctly made analysis LCA comprises four successive stages: Goal and Scope Definition, LCI—Life Cycle Inventory, LCIA—Life Cycle Impact Assessment, Interpretation. Currently, this technique is implemented in many computer programs, including SimaPro [21,22]. The analysis was performed in the SimaPro version 8.2 computer program, which enables the analysis using 68 evaluation methods. Many authors, including the authors of this publication, used the Ecoindicator 99 method to assess environmental impact [23-26]. However, due to the fact that it has been replaced by the ReCiPe method, the use of this method is proposed. The literature of the subject also uses assessment methods whose assessment result is presented in CO2 equivalent (e.g., IPCC 2013 GWP 100a or Greenhouses Gas Protocol) $[27,28]$. However, due to the way the results were presented, the ReCiPe endpoint (E) assessment method was used. The results of the LCA analysis are presented in the so-called Ecopoints (Pt), i.e., units calculated as the ratio of the total environmental load of all European residents to the number of inhabitants, then multiplied by 1000. Material and energy flows are based on the data contained in the Ecoinvent 3 data library. A functional unit was proposed for thermal insulation materials $-1 \mathrm{~m} 3$ and relative to the analyzed heat sources, generation of $1 \mathrm{kWh}$ of thermal energy. The system boundaries include the production phase of thermal insulation materials and boilers used for heating. The next phase of the life cycle, which has been included in the system boundary, is the phase of using boilers for heating buildings.

This article uses the LCA methodology to determine the ecological benefits resulting from thermal insulation and heat source replacement (Section 5). In particular, the LCA determines the ecological costs related to the production of thermal insulation materials, ecological costs of production of boilers, and ecological costs of generation of thermal energy.

\section{Description of the Studied Cases}

Single-family buildings were included in the research, because in Poland about $56 \%$ of the population lives in such buildings. The existing buildings (built in the 1990s), residential with a typical usable area for Polish conditions of $\left(\mathrm{B}_{1}\right) p_{u}=132.2 \mathrm{~m}^{2}$ and bigger building $\left(\mathrm{B}_{2}\right) p_{u}=198.9 \mathrm{~m}^{2}$, were accepted for the study. It should be noted here that the proposed research methodology is universal and applicable in any climate and region of the world.

The first building $\left(B_{1}\right)$ : A one-story house with an attic is studied, a free-standing (Figure $2 A, B$ ), gable roof. The walls are made of YTONG PP2/0.4 cellular concrete blocks $(\lambda=0.14 \mathrm{~W} / \mathrm{mK})$. Ceiling: TERIVA type. The roof is wooden, and the roof covering is made of sheet metal (see Table 2 and Figure 1. The roof pitch is 38 degrees. The attic insulation is made of mineral wool. The heat transfer coefficient of the vertical external opaque walls is $U_{0}=0.398 \mathrm{~W} /\left(\mathrm{m}^{2} \cdot \mathrm{K}\right)$, and the area of these walls $p=199.04 \mathrm{~m}^{2}$. 
Table 2. Selected information on buildings.

\begin{tabular}{|c|c|c|}
\hline \multirow{2}{*}{ Buildings Elements } & \multicolumn{2}{|c|}{ Material Used } \\
\hline & The First Building $\left(B_{1}\right)$ & The Second Building $\left(B_{2}\right)$ \\
\hline Walls & $\begin{array}{l}\text { YTONG PP2/0.4 cellular concrete } \\
\text { blocks }(\lambda=0.14 \mathrm{~W} / \mathrm{mK})\end{array}$ & $\begin{array}{l}\text { YTONG PP2/0.4 cellular concrete } \\
\text { blocks }(\lambda=0.11 \mathrm{~W} / \mathrm{mK})\end{array}$ \\
\hline Roof & Wooden, mineral wool, sheet metal & Wooden, mineral wool, ceramic tiles \\
\hline Ceiling & TERIVA type & TERIVA type \\
\hline Floor on the ground & $\begin{array}{c}\text { Concrete screed, polystyrene EPS, } \\
\text { anti-moisture insulation, concrete } \\
\text { sleeper }\end{array}$ & $\begin{array}{c}\text { Concrete screed, polystyrene EPS, } \\
\text { anti-moisture insulation, concrete } \\
\text { sleeper }\end{array}$ \\
\hline Windows and door & PVC & PVC \\
\hline$p_{u}\left[\mathrm{~m}^{2}\right]$ & 132.2 & 198.9 \\
\hline$p\left[\mathrm{~m}^{2}\right]$ & 199.04 & 266.41 \\
\hline$U_{0}\left[\mathrm{~W} /\left(\mathrm{m}^{2} \cdot \mathrm{K}\right)\right]$ & 0.398 & 0.285 \\
\hline
\end{tabular}

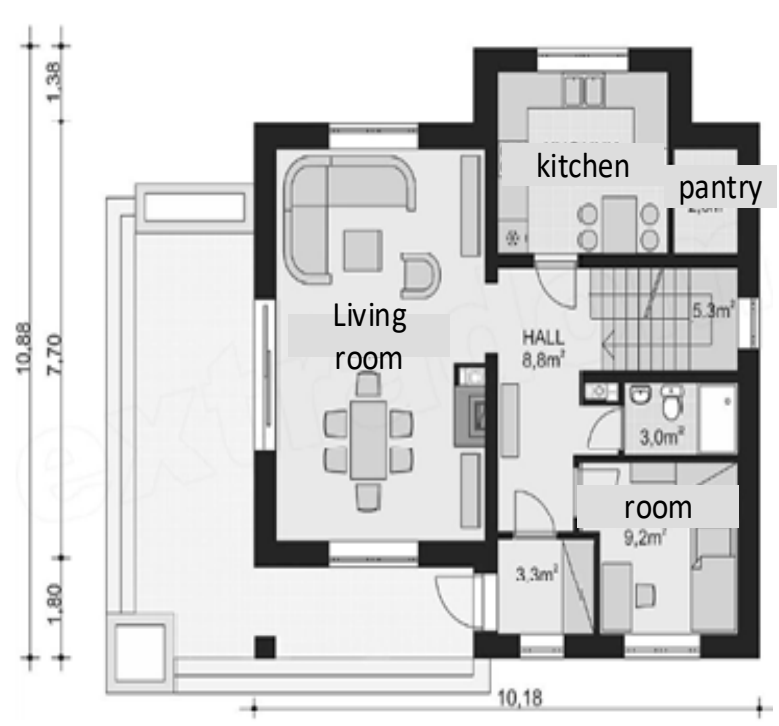

(A)

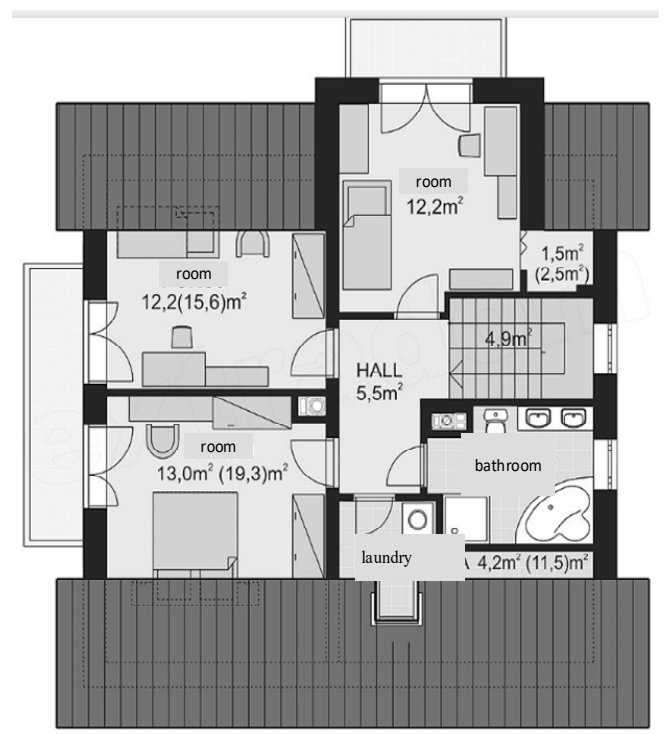

(B)

Figure 1. Buildings external partitions (B1 and B2). (A) Before thermo-modernization. (B) After thermo-modernization. 1. Cellular concrete blocks; 2. Plaster; 3. Thermal insulation.

The second building $\left(\mathrm{B}_{2}\right)$ : A one-story house with an attic is studied, a free-standing (Figure $\left.3 \mathrm{~A}, \mathrm{~B}\right)$, hipped roof. The walls are made of YTONG PP2/0.4 cellular concrete blocks $(\lambda=0.11 \mathrm{~W} / \mathrm{mK})$. Ceiling: TERIVA type. The roof is wooden, and the roof covering is made of ceramic tiles (see Table 2 and Figure 1). The roof pitch is 38 degrees. The attic insulation is made of mineral wool. The heat transfer coefficient of the vertical external opaque walls is $U_{0}=0.285 \mathrm{~W} /\left(\mathrm{m}^{2} \cdot \mathrm{K}\right)$, and the area of these walls $p=266.41 \mathrm{~m}^{2}$. The design temperature for the garage is $8{ }^{\circ} \mathrm{C}$.

The value of heat transfer coefficient is in accordance with PN-91/B-02020. At present, the Regulation of the Minister of Transport, Construction and Maritime Economy is in force in Poland, which sets the value of the heat transfer coefficient at a level not higher than $U_{n}=0.23$ $\mathrm{W} /\left(\mathrm{m}^{2} \cdot \mathrm{K}\right)$ for vertical walls $[29,30]$. The calculated internal temperature is $20^{\circ} \mathrm{C}$. Ventilation is natural, no cooling system.

The buildings are located in Zielona Góra in the II climate zone. Poland's climatic zones are described in [31]. The used heat source is a traditional coal boiler in Poland with an average annual efficiency of $66 \%$. A gas flow water heater is used to prepare domestic hot water. 

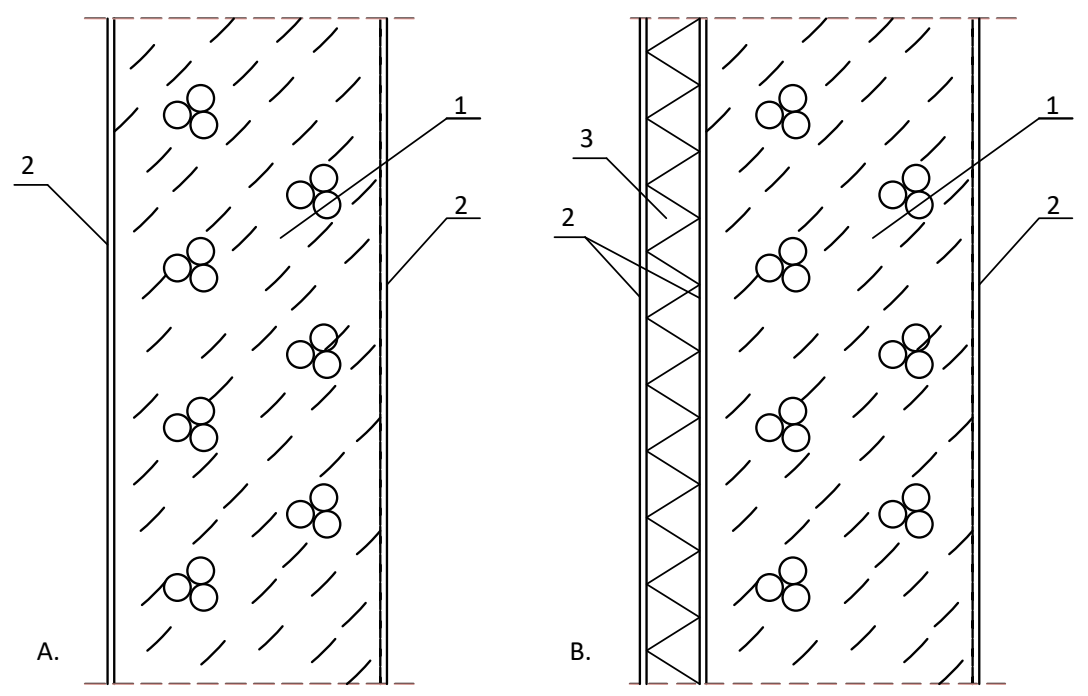

Figure 2. (A) Ground floor plan, (B) Attic floor plan. Source: Reference [32].

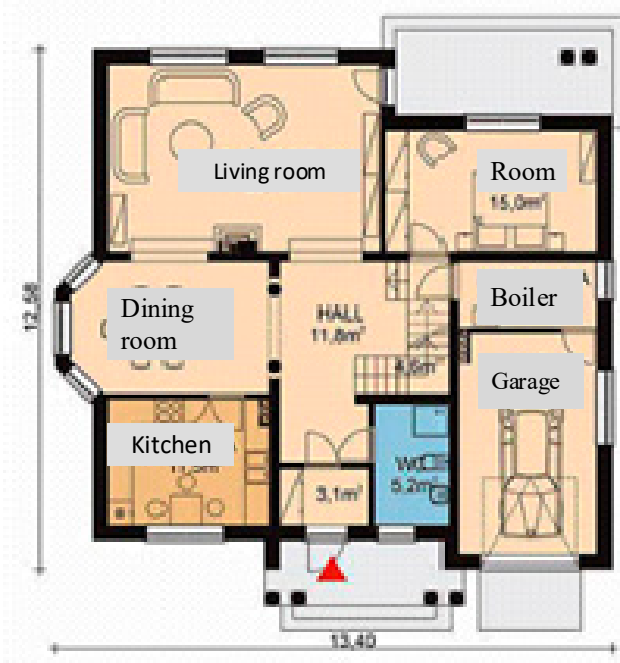

(A)

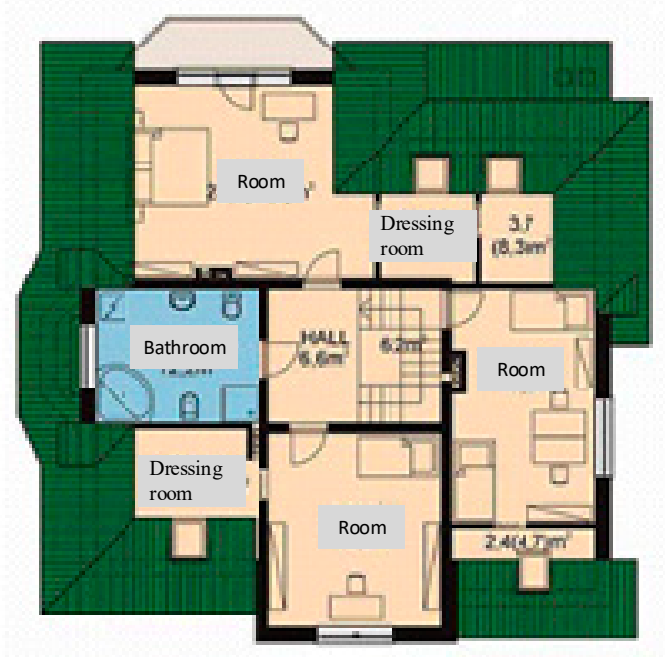

(B)

Figure 3. (A) Ground floor plan, (B) attic floor plan. Source: Reference [33].

It was assumed that the buildings after thermo-modernization would have a heat transfer coefficient of $U_{n}=0.23 \mathrm{~W} /\left(\mathrm{m}^{2} \cdot \mathrm{K}\right)$, in accordance with the provisions in force in Poland. Calculations of the buildings energy demand (before and after thermo-modernization) were made using the CERTO computer program [34].

The demand for usable energy for heating and ventilation purposes is at the level of:

The first building $\left(B_{1}\right)$ :

- For the building before thermo-modernization: $D u_{0}=108.58 \mathrm{kWh} /\left(\mathrm{m}^{2} \cdot\right.$ year);

- For the building after thermo-modernization: $D u_{n}=89.0 \mathrm{kWh} /\left(\mathrm{m}^{2} \cdot\right.$ year $)$.

The second building $\left(\mathrm{B}_{2}\right)$ :

- For the building before thermo-modernization: $D u_{0}=94.06 \mathrm{kWh} /\left(\mathrm{m}^{2} \cdot\right.$ year);

- For the building after thermo-modernization: $D u_{n}=89.51 \mathrm{kWh} /\left(\mathrm{m}^{2} \cdot\right.$ year $)$.

Two thermal insulation materials have been proposed for thermal insulation: Mineral wool with thermal conductivity $\lambda=0.039 \mathrm{~W} / \mathrm{mK}$ and Polystyrene EPS with thermal conductivity $\lambda=0.040 \mathrm{~W} / \mathrm{mK}$.

The service life of boilers and thermal insulation $N=10$ years has been assumed [35]. 


\section{Ecological Benefits Resulting from Thermal Insulation and Heat Source Replacement}

A number of investments are usually subject to economic assessment; however, due to the growing ecological awareness of society, it is important to provide knowledge on the impact of investments on the environment. The investment in the form of thermo-modernization is associated with increased pressure on the environment, and it is caused, e.g., by production of thermal insulation materials, transport, consumption of electricity, etc. The measurable ecological benefit of the thermo-modernization investment is the reduction of the demand for usable energy. When it comes to replacing a coal-fired boiler with a gas-fired (or heating oil-fired) boiler, the measurable benefit will be reduced emissions of pollutants into the atmosphere, while the burden on the environment will be to produce a new gas-fired or heating oil-fired boiler. The existing building together with the existing infrastructure used, among others, for heating, is treated as the initial state. The essence of this article is to demonstrate ecological benefits or costs caused by this thermo-modernization investment.

\subsection{Mathematical Model for Determining Ecological Costs Related to Thermo-Modernization}

Due to the determination of the demand for usable energy in relation to $1 \mathrm{~m}^{2}$ of usable area, similarly, it was done with ecological costs. The ecological costs of thermo-modernization consist of three factors: Ecological costs of replacing the boiler $C_{S}$, ecological costs related to the production of thermal insulation materials $C_{I}$ and reduction of ecological costs of heating $C_{H}$. They can be described by the formula:

$$
C_{\text {ekol }}=C_{S}+C_{I}-C_{H}\left[\mathrm{Pt} / \mathrm{m}^{2}\right]
$$

The individual costs can be determined in the following way:

$$
C_{S}=K_{p} / p_{u}\left[\mathrm{Pt} / \mathrm{m}^{2}\right]
$$

where $K_{p}[\mathrm{Pt} / \mathrm{item}]$ are ecological costs of production of one boiler, $p_{u}$-as before;

$$
C_{I}=K_{l} \cdot d \cdot p / p_{u}\left[\mathrm{Pt} / \mathrm{m}^{2}\right]
$$

where $K_{l}\left[\mathrm{Pt} / \mathrm{m}^{3}\right]$ is the result of LCA analysis for a thermal insulation material, $d[\mathrm{~m}]$ - the thickness of the thermal insulation layer, $p$ and $p_{u}$-as before.

The thickness of the thermal insulation layer is determined in such a way as after thermal insulation, and the heat transfer coefficient for the wall is $U_{n}=0.23 \mathrm{~W} /\left(\mathrm{m}^{2} \cdot \mathrm{K}\right)$. Therefore, $d=\lambda \cdot\left(1 / U_{n}-1 / U_{0}\right)$.

The reduction of ecological heating costs is influenced by both the boiler replacement and the implementation of thermal insulation:

$$
C_{H}=N \cdot\left(D u_{0} \cdot K_{e}\left(\mathrm{~S}_{0}\right)-D u_{n} \cdot K_{e}\left(\mathrm{~S}_{\mathrm{i}}\right)\right)\left[\mathrm{Pt} / \mathrm{m}^{2}\right]
$$

where $N$-number of years of boiler use and thermal insulation, $K_{e}\left(\mathrm{~S}_{\mathrm{i}}\right)[\mathrm{Pt} / \mathrm{kWh}$ — the result of LCA analysis, generation of $1 \mathrm{kWh}$ of thermal energy for the analyzed heat source $\mathrm{S}_{\mathrm{i}}, I=0,1,2, D u_{0}$ and $D u_{n}$ —as before.

When only a boiler is replaced, then:

$$
C_{H}=N \cdot\left(D u_{0} \cdot K_{e}\left(\mathrm{~S}_{0}\right)-D u_{0} \cdot K_{e}\left(\mathrm{~S}_{\mathrm{i}}\right)\right)\left[\mathrm{Pt} / \mathrm{m}^{2}\right] .
$$

\subsection{The Results of Ecological Analysis for the Studied Variants}

Table 3 presents the results of the LCA analysis of the two proposed thermal insulation variants (I1, I2), which are the materials most commonly used in Poland. Let us note that the production of mineral wool represents an almost three times higher environmental load compared to the production of EPS. 
Table 3. Results of LCA analysis of thermal insulation materials.

\begin{tabular}{ccc}
\hline Thermal Insulation Material & Mineral Wool $\left(\mathbf{I}_{\mathbf{1}}\right)$ & Polystyrene EPS $\left(\mathbf{I}_{\mathbf{2}}\right)$ \\
\hline$K_{l}\left[\mathrm{Pt} / \mathrm{m}^{3}\right]$ & 19.10 & 6.77 \\
\hline
\end{tabular}

Table 4 presents the environmental load resulting from heat production in an old coal boiler $\left(\mathrm{S}_{0}\right)$ and in a gas boiler $\left(\mathrm{S}_{1}\right)$ and in an oil boiler $\left(\mathrm{S}_{2}\right)$, which can alternatively replace an inefficient coal boiler. The environmental load resulting from the production of a particular boiler is also given. It can be seen that the change of the $S_{0}$ boiler to $S_{1}$ or $S_{2}$ brings a very large reduction in the environmental load during heat production, in the case of $S_{1}$ the reduction is more than 4-fold and in the case of $S_{2}$-more than 3-fold. The ecological costs of producing $S_{1}$ and $S_{2}$ boilers are similar.

Table 4. The result of LCA analysis of heat production and boilers.

\begin{tabular}{cccc}
\hline Heat Source & Coal Boiler $\left(\mathbf{S}_{\mathbf{0}}\right)$ & Gas Boiler $\left(\mathbf{S}_{\mathbf{1}}\right)$ & Fuel Oil Boiler $\left(\mathbf{S}_{\mathbf{2}}\right)$ \\
\hline$K_{e}[\mathrm{Pt} / \mathrm{kWh}]$ & 0.124 & 0.027 & 0.039 \\
\hline Production of boiler $K_{p}[\mathrm{Pt} /$ item $]$ & - & 401 & 395 \\
\hline
\end{tabular}

Using the methodology described in p. 5.1, the required thickness of thermal insulation $d$ was determined, followed by the costs of $C_{S}$ and $C_{I}$ (see Table 5) for buildings $B_{1}$ and $B_{2}$.

Table 5. Ecological costs of replacing the $C_{S}$ boiler and ecological costs associated with the production of $C_{I}$ thermal insulation materials.

\begin{tabular}{ccccc}
\hline Building & \multicolumn{2}{c}{$\mathbf{B}_{\mathbf{1}}$} \\
\hline Heat Source & Gas Boiler $\left(\mathbf{S}_{\mathbf{1}}\right)$ & Fuel Oil Boiler $\left(\mathbf{S}_{\mathbf{2}}\right)$ & Gas Boiler $\left(\mathbf{S}_{\mathbf{1}}\right)$ & Fuel Oil Boiler $\left(\mathbf{S}_{\mathbf{2}}\right)$ \\
\hline$C_{S}\left[\mathrm{Pt} / \mathrm{m}^{2}\right]$ & 3.033 & 2.988 & 2.016 & 1.986 \\
\hline $\begin{array}{c}\text { Thermal insulation } \\
\text { material }\end{array}$ & Mineral wool $\left(\mathbf{I}_{\mathbf{1}}\right)$ & Polystyrene EPS $\left(\mathbf{I}_{\mathbf{2}}\right)$ & Mineral wool $\left(\mathbf{I}_{\mathbf{1}}\right)$ & Polystyrene EPS $\left(\mathbf{I}_{\mathbf{2}}\right)$ \\
\hline$d[\mathrm{~m}]$ & 0.072 & 0.073 & 0.033 & 0.034 \\
\hline$C_{I}\left[\mathrm{Pt} / \mathrm{m}^{2}\right]$ & 2.070 & 0.744 & 0.844 & 0.308 \\
\hline
\end{tabular}

Using the Formulas (4) and (5) the reduction of ecological heating costs as a result of thermo-modernization investment was determined, the results are summarized in Table 6. As seen, the replacement of the boiler has a much greater impact on the reduction of ecological heating costs than the implementation of thermal insulation, both for the building $B_{1}$ and $B_{2}$.

Finally, the ecological costs of thermo-modernization $C_{\text {ekol }}$ are set (Table 7) for eight possible thermo-modernization variants, for both buildings. Variants (1) and (2) relate only to boiler replacement, and variants (3) and (4) relate to the very implementation of the thermal insulation. Further variants from (5) to (8) are associated with boiler replacement and thermal insulation.

Table 6. Reduction of ecological heating costs.

\begin{tabular}{|c|c|c|c|c|c|c|}
\hline \multirow{2}{*}{$\begin{array}{c}\text { Building } \\
\text { Heat Source }\end{array}$} & \multicolumn{3}{|c|}{$\mathbf{B}_{1}$} & \multicolumn{3}{|c|}{$\mathbf{B}_{2}$} \\
\hline & $\begin{array}{c}\text { Coal } \\
\text { Boiler }\left(\mathrm{S}_{0}\right)\end{array}$ & $\begin{array}{c}\text { Gas Boiler } \\
\left(\mathrm{S}_{1}\right)\end{array}$ & $\begin{array}{c}\text { Fuel Oil } \\
\text { Boiler }\left(S_{2}\right)\end{array}$ & $\begin{array}{c}\text { Coal } \\
\text { Boiler }\left(\mathrm{S}_{0}\right)\end{array}$ & $\begin{array}{c}\text { Gas Boiler } \\
\left(\mathrm{S}_{1}\right)\end{array}$ & $\begin{array}{c}\text { Fuel Oil } \\
\text { Boiler }\left(S_{2}\right)\end{array}$ \\
\hline $\begin{array}{c}C_{H}\left[\mathrm{Pt} / \mathrm{m}^{2}\right] \\
\text { (with thermal } \\
\text { insulation) }\end{array}$ & 24.279 & 110.609 & 99.929 & 5.642 & 92.467 & 81.726 \\
\hline $\begin{array}{c}C_{H}\left[\mathrm{Pt} / \mathrm{m}^{2}\right] \\
\text { (without thermal } \\
\text { insulation) }\end{array}$ & - & 105.323 & 92.293 & - & 91.238 & 79.951 \\
\hline
\end{tabular}


Table 7. Ecological costs of thermo-modernization.

\begin{tabular}{cccc}
\hline \multicolumn{2}{c}{ Building } & $\mathbf{B}_{\mathbf{1}}$ & $\mathbf{B}_{\mathbf{2}}$ \\
\hline Variant & Description & $C_{\text {ekol }}\left[\mathbf{P t} / \mathbf{m}^{2}\right]$ & $C_{\text {ekol }}\left[\mathbf{P t} / \mathbf{m}^{2}\right]$ \\
\hline$(1)$ & $\mathrm{S}_{0} \rightarrow \mathrm{S}_{1}$ & -102.29 & -89.222 \\
\hline$(2)$ & $\mathrm{S}_{0} \rightarrow \mathrm{S}_{2}$ & -89.305 & -77.965 \\
\hline$(3)$ & $\mathrm{U} \rightarrow \mathrm{I}_{1}$ & -22.209 & -4.798 \\
\hline$(4)$ & $\mathrm{U}_{0} \rightarrow \mathrm{I}_{2}$ & -23.535 & -5.334 \\
\hline$(5)$ & $\mathrm{S}_{0} \mathrm{U}_{0} \rightarrow \mathrm{S}_{1} \mathrm{I}_{1}$ & -105.506 & -89.607 \\
\hline$(6)$ & $\mathrm{S}_{0} \mathrm{U}_{0} \rightarrow \mathrm{S}_{1} \mathrm{I}_{2}$ & -106.832 & -90.143 \\
\hline$(7)$ & $\mathrm{S}_{0} \mathrm{U}_{0} \rightarrow \mathrm{S}_{2} \mathrm{I}_{1}$ & -94.871 & -78.896 \\
\hline$(8)$ & $\mathrm{S}_{0} \mathrm{U}_{0} \rightarrow \mathrm{S}_{2} \mathrm{I}_{2}$ & -96.197 & -79.432 \\
\hline
\end{tabular}

Let us note that in all variants the ecological costs of thermo-modernization came out negative, therefore a reduction of the environmental load is achieved. Much greater environmental benefits are associated with boiler replacement. The most favorable, however, are variants (5) and (6), in which the boiler is replaced from $S_{0}$ to $S_{1}$ and the implementation of thermal insulation, both for the building $B_{1}$ and $\mathrm{B}_{2}$.

\section{Economic Benefits of Thermal Insulation and Heat Source Replacement}

This point deals with the economic assessment of the thermo-modernization investment in question. Similarly, to the ecological analysis, the option of boiler replacement and thermal insulation is also taken into consideration.

\subsection{Mathematical Model for Determining Economic Costs Associated with Thermo-Modernization}

Since the demand for usable energy is determined in relation to $1 \mathrm{~m}^{2}$ of usable area, similarly, it was done with economic costs. The economic costs of thermo-modernization also include three factors: (1) The economic costs of replacing the boiler $E_{S}$, (2) the economic costs associated with the production of thermal insulation materials $E_{I}$, and (3) the reduction of the economic costs of heating $E_{H}$. They can be described by the formula:

$$
E_{\text {ekon }}=E_{S}+E_{I}-E_{H}\left[\mathrm{PLN} / \mathrm{m}^{2}\right]
$$

The individual costs can be determined as follows:

$$
E_{S}=\left(K_{z}+K_{i}\right) / p_{u}\left[\mathrm{PLN} / \mathrm{m}^{2}\right]
$$

where $K_{z}$ [PLN/item] are the economic costs of buying one boiler (4.40 PLN $\approx 1$ Euro), $K_{i}[\mathrm{PLN} /$ item $]$ - economic costs of installing one boiler, $p_{u}$ —as before;

$$
E_{I}=\left(K_{m} \cdot d+K_{w}\right) p / p_{u}\left[\mathrm{PLN} / \mathrm{m}^{2}\right]
$$

where $K_{m}\left[\mathrm{PLN} / \mathrm{m}^{3}\right]$ is the economic cost of purchasing thermal insulation material, $d[\mathrm{~m}]$-thickness of the thermal insulation layer, $K_{w}\left[\mathrm{PLN} / \mathrm{m}^{2}\right]$ — cost of making thermal insulation, $d, p$ and $p_{u}$-as before.

The reduction of economical heating costs, as in the case of ecological analysis, is influenced by both the boiler replacement and the implementation of thermal insulation:

$$
E_{H}=S_{N} \cdot\left(D u_{0} \cdot K_{c}\left(\mathrm{~S}_{0}\right)-D u_{n} \cdot K_{c}\left(\mathrm{~S}_{\mathrm{i}}\right)\right)\left[\mathrm{PLN} / \mathrm{m}^{2}\right]
$$


where $S_{N}=\sum_{j=1}^{N} \frac{(1+s)^{j}}{(1+r)^{j}}$-cumulative discount factor, $r$-real annual interest rate, $s$-real annual growth (in percentage) of heating costs, $K_{c}\left(\mathrm{~S}_{\mathrm{i}}\right)[\mathrm{PLN} / \mathrm{kWh}]$-the cost of $1 \mathrm{kWh}$ of thermal energy for the analyzed heat source $S_{i}, i=0,1,2 ; N, D u_{o}$ and $D u_{n}$-as before.

When only a boiler is replaced, then:

$$
E_{H}=S_{N} \cdot\left(D u_{0} \cdot K_{c}\left(\mathrm{~S}_{0}\right)-D u_{0} \cdot K_{c}\left(\mathrm{~S}_{\mathrm{i}}\right)\right)\left[\mathrm{PLN} / \mathrm{m}^{2}\right]
$$

\subsection{The Results of the Economic Analysis for the Studied Variants}

Table 8 summarizes the economic costs ( 4.40 PLN $\approx 1$ Euro) of purchasing $K_{m}$ and performance of $K_{w}$ thermal insulation for the proposed thermal insulation variants $\left(\mathrm{I}_{1}, \mathrm{I}_{2}\right)$. Lower costs are associated with thermal insulation using EPS foam.

Table 8. The costs of purchase and implementation of thermal insulation.

\begin{tabular}{ccc}
\hline Thermal Insulation Material & Mineral Wool $\left(\mathbf{I}_{\mathbf{1}}\right)$ & Polystyrene EPS $\left(\mathbf{I}_{\mathbf{2}}\right)$ \\
\hline$K_{m}\left[\mathrm{PLN} / \mathrm{m}^{3}\right]$ & 226.60 & 143.00 \\
\hline$K_{w}\left[\mathrm{PLN} / \mathrm{m}^{2}\right]$ & 40.00 & 35.00 \\
\hline
\end{tabular}

Table 9 presents the cost of $1 \mathrm{kWh}$ of thermal energy for the analyzed heat sources. The purchase and installation costs of a particular boiler are also given. Changing the $S_{0}$ boiler to $S_{1}$ or $S_{2}$, unfortunately, brings an increase in the costs of obtaining thermal energy compared to the $\mathrm{S}_{0}$ boiler, in the case of the $\mathrm{S}_{2}$ boiler more than two times. The costs of buying and installing the $\mathrm{S}_{2}$ boiler are much higher than the $S_{1}$ boiler.

Table 9. Economic costs of heat energy and the purchase and installation of boilers.

\begin{tabular}{cccc}
\hline Heat Source & Coal Boiler $\left(\mathbf{S}_{\mathbf{0}}\right)$ & Gas Boiler $\left(\mathbf{S}_{\mathbf{1}}\right)$ & Fuel Oil Boiler $\left(\mathbf{S}_{\mathbf{2}}\right)$ \\
\hline$K_{c}[\mathrm{PLN} / \mathrm{kWh}]$ & 0.164 & 0.210 & 0.339 \\
\hline The cost of buying a boiler $K_{z}[\mathrm{PLN} /$ item $]$ & - & 3000 & 11000 \\
\hline Boiler installation cost $K_{i}[\mathrm{PLN} /$ item $]$ & - & 5000 & 10000 \\
\hline
\end{tabular}

Source: Reference [36].

Using the methodology, described in p. 6.1, and for the determined thickness of thermal insulation $d$ economic costs, $E_{S}$ and $E_{I}$ were determined (see Table 10), for buildings $\mathrm{B}_{1}$ and $\mathrm{B}_{2}$.

Table 10. Economic costs of replacing the boiler $E_{S}$ and economic costs associated with thermal insulation $E_{I}$.

\begin{tabular}{ccccc}
\hline Building & \multicolumn{2}{c}{$\mathbf{B}_{\mathbf{1}}$} & $\mathbf{B}_{\mathbf{2}}$ \\
\hline Heat Source & Gas Boiler $\left(\mathbf{S}_{\mathbf{1}}\right)$ & Fuel Oil Boiler $\left(\mathbf{S}_{\mathbf{2}}\right)$ & Gas Boiler $\left(\mathbf{S}_{\mathbf{1}}\right)$ & Fuel Oil Boiler $\left(\mathbf{S}_{\mathbf{2}}\right)$ \\
\hline$E_{S}\left[\mathrm{PLN} / \mathrm{m}^{2}\right]$ & 60.51 & 158.85 & 40.22 & 105.58 \\
\hline Thermal insulation material & Mineral wool $\left(\mathbf{I}_{\mathbf{1}}\right)$ & Polystyrene EPS $\left(\mathbf{I}_{\mathbf{2}}\right)$ & Mineral wool $\left(\mathbf{I}_{\mathbf{1}}\right)$ & Polystyrene EPS $\left(\mathbf{I}_{\mathbf{2}}\right)$ \\
\hline$E_{I}\left[\mathrm{PLN} / \mathrm{m}^{2}\right]$ & 84.79 & 68.41 & 63.59 & 53.39 \\
\hline
\end{tabular}

Using the formulas (9) and (10), the reduction of economical heating costs as a result of thermo-modernization investment was determined, the results are summarized in Table 11. Interest rates $r=5 \%$ and $s=2 \%$ were used to determine $S_{N}$. As can be seen, only in the case of thermal insulation without replacing the $\mathrm{S}_{0}$ boiler with another one, a positive value was obtained. The higher costs are when replacing the $S_{0}$ boiler with $S_{2}$, mainly due to over two times higher costs of heat energy 
production. The implementation of thermal insulation significantly reduces the economic costs of heating, both for the building $\mathrm{B}_{1}$ and $\mathrm{B}_{2}$.

Table 11. Reduction of economical heating costs.

\begin{tabular}{ccccccc}
\hline Building & \multicolumn{3}{c}{$\mathbf{B}_{\mathbf{1}}$} & & $\mathbf{B}_{\mathbf{2}}$ \\
\hline Heat Source & $\begin{array}{c}\text { Coal } \\
\text { Boiler }\left(\mathbf{S}_{\mathbf{0}}\right)\end{array}$ & $\begin{array}{c}\text { Gas Boiler } \\
\left.\mathbf{( S}_{\mathbf{1}}\right)\end{array}$ & $\begin{array}{c}\text { Fuel oil } \\
\text { Boiler }\left(\mathbf{S}_{\mathbf{2}}\right)\end{array}$ & $\begin{array}{c}\text { Coal } \\
\text { Boiler }\left(\mathbf{S}_{\mathbf{0}}\right)\end{array}$ & $\begin{array}{c}\text { Gas Boiler } \\
\left.\mathbf{( S}_{\mathbf{1}}\right)\end{array}$ & $\begin{array}{c}\text { Fuel Oil } \\
\text { Boiler }\left(\mathbf{S}_{\mathbf{2}}\right)\end{array}$ \\
\hline $\begin{array}{c}E_{H}\left[\mathrm{PLN} / \mathrm{m}^{2}\right] \\
\text { (with thermal insulation) }\end{array}$ & 27.47 & -7.55 & -105.78 & 6.38 & -28.84 & -127.64 \\
\hline $\begin{array}{c}E_{H}\left[\mathrm{PLN} / \mathrm{m}^{2}\right] \\
\text { (without thermal insulation) }\end{array}$ & 0.00 & -42.73 & -162.57 & 0.00 & -37.02 & -140.83 \\
\hline
\end{tabular}

Finally, the set economic costs of thermo-modernization $E_{\text {ekon }}$ are summarized (Table 12) for the same eight thermo-modernization variants and for both buildings as in the case of ecological analysis. Similarly, variants (1) and (2) relate only to boiler replacement, variants (3) and (4) are associated with the very implementation of thermal insulation, and variants (5) to (8) are associated with boiler replacement and thermal insulation.

Table 12. Economic costs of thermo-modernization.

\begin{tabular}{cccc}
\hline \multicolumn{2}{c}{ Building } & $\mathbf{B}_{\mathbf{1}}$ & $\mathbf{B}_{\mathbf{2}}$ \\
\hline Variant & Description & $E_{\text {ekon }}\left[\mathbf{P L N} / \mathbf{m}^{2}\right]$ & $E_{\text {ekon }}\left[\mathbf{P L N} / \mathbf{m}^{2}\right]$ \\
\hline$(1)$ & $\mathrm{S}_{0} \rightarrow \mathrm{S}_{1}$ & 103.24 & 77.24 \\
\hline$(2)$ & $\mathrm{S}_{0} \rightarrow \mathrm{S}_{2}$ & 321.42 & 246.41 \\
\hline$(3)$ & $\mathrm{U}_{0} \rightarrow \mathrm{I}_{1}$ & 57.32 & 57.21 \\
\hline$(4)$ & $\mathrm{U}_{0} \rightarrow \mathrm{I}_{2}$ & 40.94 & 47.01 \\
\hline$(5)$ & $\mathrm{S}_{0} \mathrm{U}_{0} \rightarrow \mathrm{S}_{1} \mathrm{I}_{1}$ & 152.85 & 132.65 \\
\hline$(6)$ & $\mathrm{S}_{0} \mathrm{U}_{0} \rightarrow \mathrm{S}_{1} \mathrm{I}_{2}$ & 136.47 & 122.45 \\
\hline$(7)$ & $\mathrm{S}_{0} \mathrm{U}_{0} \rightarrow \mathrm{S}_{2} \mathrm{I}_{1}$ & 349.42 & 296.81 \\
\hline$(8)$ & $\mathrm{S}_{0} \mathrm{U}_{0} \rightarrow \mathrm{S}_{2} \mathrm{I}_{2}$ & 333.04 & 286.61 \\
\hline
\end{tabular}

Unfortunately, the economic costs of thermo-modernization came out positive in all variants. This means that the economic costs of using the building will increase as a result of such a thermo-modernization investment. The lowest economic costs of thermo-modernization were obtained for variants (3) and (4), in which only thermal insulation is provided, both for the building $B_{1}$ and $B_{2}$.

\section{Conclusions and Summary}

In the classic understanding, "investments" are assets that an entity has in order to obtain economic benefits from them, resulting from an increase in the value of those assets, obtaining income in the form of interest, dividends (shares in profits) or other benefits, including commercial transactions, in particular financial assets and those real estate and intangible assets that are not used by the entity, but are held by the entity to achieve these benefits [37]. Taking into consideration the obtained research results, thermo-modernization of the "medium" should not be referred to as an investment but as a venture. The classic definition of "investment" does not take into consideration other benefits than economic benefits. Undoubtedly, the thermo-modernization project generates high ecological benefits, ranging from the use of only thermal insulation on the building wall or replacement of the boiler ("low" thermo-modernization) to the combined application of thermal insulation and replacement of the boiler with the ecological one ("medium" thermo-modernization). 
In Poland, the cheapest source of heat are coal-fired boilers. The choice of the type of heat source used to heat the building is most often aimed at reducing operating costs. Often, this is also associated with the lack of access to infrastructure to provide fuel to the boiler (e.g., gas pipeline). The article does not take into account the preferences of users of various types of boilers depending on the convenience of use.

From an economic point of view, the thermo-modernization project does not generate profits in the considered period. This is important information for policy-makers who should develop subsidy programs supporting the replacement of boilers for ecological ones, taking into account the costs of this project.

It should be highlighted that in Poland there is a subsidy system for replacing boilers with ecological ones, it is implemented at the level of local governments (municipalities) and at the central level. Boiler replacement subsidies cannot be obtained from two sources. The amount of subsidies at the level of local governments largely depends on the wealth of the municipality, as well as the type of new heat source used. However, due to the high cost of replacing and installing boilers and much higher costs of energy production, these surcharges should be at a higher level throughout Poland. In this case, the cities of Warsaw and Krakow can be a model for others, where $100 \%$ of the costs of replacing the boiler with an ecological one (in Warsaw maximum 40,000 PLN) is co-financed. In other Polish cities, few Municipal Offices declare 100\% co-financing; however, the maximum value of co-financing is not higher than 15,000 PLN. Other cities in Poland declare funding at the level of $30 \div 80 \%$ of the project costs.

In Poland, there are no fees for emissions of pollutants into the atmosphere for individual users of the environment, and they occur only for enterprises. Therefore, decision-makers have no other option to influence individual users of the environment but by means of financial incentives that can significantly contribute to improving the atmosphere in Poland.

From an ecological point of view, each of the considered projects ("low", "medium") is "environmentally friendly", even after taking into consideration the negative aspects generated during the production of thermal insulation or a new boiler.

The main conclusion that results from the analysis is the lack of economic benefits for the investor from the thermo-modernization of the "medium". This is mainly due to the much higher cost of fuel in ecological boilers (natural gas boiler and fuel oil boiler), as well as the high cost of boiler replacement. Taking into account the tendency of fuel prices on the market, one cannot expect any economic benefits in this aspect, but rather, one can be sure of higher operating costs of ecological boilers. It should be emphasized that thermo-modernization of the building generates high ecological benefits. The greatest benefits are generated in the case of boiler replacement and thermal insulation implementation. Taking into account ecological and economic conditions, it is more preferable to choose a natural gas boiler rather than a fuel oil boiler.

Another aspect resulting from the economic and ecological analysis is finding answers to the questions: Does an eco-friendly project need to bring economic profits? Is it enough to have high ecological awareness to decide to invest in an enterprise that will not bring economic profits? The posed questions are research problems to which answers should be sought in scientific considerations in order to find optimal solutions in the pursuit of sustainable development.

Author Contributions: Conceptualization, J.A. and R.D.; methodology, R.D. and J.A.; software, J.A. and R.D.; validation, J.A. and R.D.; formal analysis, R.D. and J.A.; investigation, R.D. and J.A; resources and data curation, J.A. and R.D.; writing — original draft preparation, J.A. and R.D.; writing—review and editing, R.D. and J.A.; visualization, J.A. and R.D.; supervision, R.D. and J.A; project administration, J.A. and R.D. All authors have read and agreed to the published version of the manuscript.

Funding: This research received no external funding.

Conflicts of Interest: The authors declare no conflict of interest. 


\section{References}

1. Robakiewicz, M. Ustawa o wspieraniu termomodernizacji i remontów. Rynek Instal. 2009, 40-42. (In Polish)

2. Firlag, S. The renovation market in Poland. Rynek Instal. 2016, 7-8, 24-26. (In Polish)

3. BPIE; Staniaszek, D.; Firlag, S. Financing Building Energy Performance Improvement in Poland. Status Report. Available online: http://bpie.eu/wp-content/uploads/2016/01/BPIE_Financing-building-energy-inPoland_EN.pdf (accessed on 5 May 2020).

4. Szulc, T.; Kokoszka, S. Application of Rough Set Theory (RST) to forecast energy consumption in buildings undergoing. Mod. Energ. 2020, 13, 1309. [CrossRef]

5. Rønneseth, Ø.; Holck Sandberg, N.; Sartori, I. Is it possible to supply norwegian apartment blocks with 4th generation district heating? Energies 2019, 12, 941. [CrossRef]

6. Zender-Swiercza, E.; Telejko, M. Impact of insulation building on the work of ventilation. Procedia Eng. 2016, 161, 1731-1737. [CrossRef]

7. Woroniak, G.; Piotrowska-Woroniak, J. Effects of pollution reduction and energy consumption reduction in small churches in Drohiczyn community. Energy Build. 2014, 72, 51-61. [CrossRef]

8. Annibaldi, V.; Cucchiella, F.; De Berardinis, P.; Rotilio, M.; Stornelli, V. Environmental and economic benefits of optimal insulation thickness: A life-cycle cost analysis. Renew. Sustain. Energy Rev. 2019, 116, 109441. [CrossRef]

9. Dombayc1, Ö.A. The environmental impact of optimum insulation thickness for external walls of buildings. Build. Environ. 2007, 42, 3855-3859. [CrossRef]

10. Dombayc1, Ö.A.; Gölcü, M.; Pancar, Y. Optimization of insulation thickness for external walls using different energy-sources. Appl. Energy 2006, 83, 921-928. [CrossRef]

11. Nematchoua, M.K.; Raminosoa, C.R.R.; Mamiharijaona, R.; René, T.; Orosa, J.A.; Elvis, W.; Meukam, P. Study of the economical and optimum thermal insulation thickness for buildings in a wet and hot tropical climate: Case of Cameroon. Renew. Sustain. Energy Rev. 2015, 50, 1192-1202. [CrossRef]

12. Idchabani, R.; Khyad, A.; El Ganaoui, M. Optimizing insulation thickness of external walls in cold region of Morocco based on life cycle cost analysis. Energy Procedia 2017, 139, 117-121. [CrossRef]

13. Adamczyk, J.; Dylewski, R. The impact of thermal insulation investments on sustainability in the construction sector. Renew. Sustain. Energy Rev. 2017, 80, 421-429. [CrossRef]

14. PN EN 303-5:2012 Heating Boilers-Part 5: Heating Boilers for Solid Fuels, Manually and Automatically Stoked, Nominal Heat Output of up to $500 \mathrm{~kW}$-Terminology, Requirements, Testing and Marking; British Standards Institution: London, UK, 2012.

15. Gospodarka Mieszkaniowa i Infrastruktura Komunalna w 2018 r. 2019, Główny Urząd Statystyczny, Warszawa. Available online: https://stat.gov.pl/obszary-tematyczne/infrastruktura-komunalnanieruchomosci/nieruchomosci-budynki-infrastruktura-komunalna/gospodarka-mieszkaniowa-iinfrastruktura-komunalna-w-2018-r-,13,13.html (accessed on 2 May 2020). (In Polish)

16. Zużycie Energii w Gospodarstwach Domowych w 2018 r. 2019 GUS, Warszawa. Available online: https://www.google.com/url?sa=t\&rct=j\&q=\&esrc=s\&source=web\&cd=1\&cad=rja\&uact=8\&ved= 2ahUKEwiWioyQ2JXpAhVtsYsKHaoRCCsQFjAAegQIBBAB\&url=https\%3A\%2F\%2Fstat.gov.pl\% 2Fdownload $\% 2 F g f x \% 2 F$ portalinformacyjny $\% 2 F p l \% 2 F d e f a u l t a k t u a l n o s c i \% 2 F 5485 \% 2 F 12 \% 2 F 1 \% 2 F 1 \%$ 2Fzuzycie_energii_w_gospodarstwach_domowych_w_2018.pdf\&usg=AOvVaw0XzbEUZWVk8410_ 1sr9Kwr (accessed on 2 May 2020). (In Polish)

17. Stan Techniczny Budynków Jednorodzinnych w Województwie Małopolskim-Źródła Ogrzewania i Standardy Izolacyjności Cieplnej, Kraków. 2016. Available online: https://powietrze.malopolska.pl/wpcontent/uploads/2017/02/Raport-z-bada\%C5\%84-Stan-techniczny-budynk\%C3\%B3w-jednorodzinnychw-Ma\%C5\%82opolsce.pdf (accessed on 5 May 2020). (In Polish)

18. Ojczyk, G. Zużycie energii w gospodarstwach domowych zasilanych kotłami stałopalnymi małej mocy, Energy consumption in households powered by low-power solid fuel boilers. Rynek Instal. 2020, 3, 76-84. (In Polish)

19. ISO 14040 Environmental Management-Life Cycle Assessment-Principles and Framework; European Committee for Standardisation: Brussels, Belgium, 2006.

20. ISO 14044 Environmental Management-Life Cycle Assessment-Requirements and Guidelines; European Committee for Standardisation: Brussels, Belgium, 2006. 
21. SimaPro. PRé Consultants. SimaPro LCA Software. Version 7.1. Product Ecology Consultants. Netherlands. Available online: www.pre.nl/simapro (accessed on 15 June 2020).

22. Dylewski, R.; Adamczyk, J. Study on ecological cost-effectiveness for the thermal insulation of building external vertical walls in Poland. J. Clean. Prod. 2016, 133, 467-478. [CrossRef]

23. Tsioka, M.; Voudrias, E.A. Comparison of alternative management methods for phosphogypsum waste using life cycle analysis. J. Clean. Prod. 2020, 266, 121386. [CrossRef]

24. Gámez-García, D.C.; Saldaña-Márquez, H.; Gómez-Soberón, J.M.; Corral-Higuera, R.; Arredondo-Rea, S.P. Life Cycle Assessment of residential streets from the perspective of favoring the human scale and reducing motorized traffic flow. Cradle Handover Approach. Sustain. Cities Soc. 2019, 44, 332-342. [CrossRef]

25. Bajdur, W.M.; Henclik, A.; Skowron-Grabowska, B.; Iwaszczuk, N. LCA application in the assessment of new technologies of industrial effluents treatment. Desalin. Water Treat. 2016, 57, 1058-1066. [CrossRef]

26. Dzikuć, M.; Tomaszewski, M. The effects of ecological investments in the power industry and their financial structure: A case study for Poland. J. Clean. Prod. 2016, 118, 48-53. [CrossRef]

27. Scrucca, F.; Ingrao, C.; Maalouf, C.; Polidori, G.; Messineo, A.; Arcidiacono, C.; Asdrubali, F. Energy and carbon footprint assessment of production of hemp hurds for application in buildings. Environ. Impact Assess. Rev. 2020, 84, 106417. [CrossRef]

28. Yadav, G.; Dubey, B.K.; Sen, R. A comparative life cycle assessment of microalgae production by $\mathrm{CO}_{2}$ sequestration from flue gas in outdoor raceway ponds under batch and semi-continuous regime. J. Clean. Prod. 2020, 258, 120703. [CrossRef]

29. PN-B/91-02020-Ochrona Cieplna Budynków. Wymagania i Obliczenia. Thermal Protection of Buildings. Requirements and Calculations. Available online: http://normy.ekoinfonet.pl/komitety.php?komitet=KT\% 20179,\%20Ochrony\%20Cieplnej\%20Budynk\%C3\%B3w\&kat=Ochrona\%20cieplna\%20budynk\%C3\%B3w (accessed on 24 August 2020). (In Polish)

30. Rozporządzenie ministra transportu, budownictwa i Gospodarki morskiej z dnia 5 lipca 2013 r. zmieniające rozporządzenie w sprawie warunków technicznych, jakim powinny odpowiadać budynki i ich usytuowanie, Dz. U. 2013, nr 0, poz. 926 Regulation of the Minister of Transport, Construction and Maritime Economy of July 5, 2013 Amending the Regulation on the Technical Conditions to be Met by Buildings and Their Location. Available online: https://www.warsztatarchitekta.pl/doc/legislacja/2016-12-19-lex-dz-u-2013-926zm-rozporzadzenie-w-sprawie.pdf (accessed on 24 August 2020). (In Polish)

31. Dylewski, R.; Adamczyk, J. The environmental impacts of thermal insulation of buildings including the categories of damage: A Polish case study. J. Clean. Prod. 2016, 137, 878-887. [CrossRef]

32. Projekt Domu APS 004 New. Available online: https://www.extradom.pl/projekt-domu-aps-004-LUA1227 (accessed on 15 April 2020).

33. Projekt Domu APS 087. Available online: https://www.extradom.pl/projekt-domu-aps-087-LUA1098 (accessed on 30 July 2020).

34. Certo. 2014. Available online: http://cieplej.pl/index_daes.php5?dzial=3\&kat=14 (accessed on 20 May 2020).

35. Jóskowski, M. Kocioł gazowy do wymiany-aspekty techniczne kotłowni i kotłów. InstalReport 2014, 10, 28-31. (In Polish)

36. Koszt roczny ogrzewania domu o powierzchni $150 \mathrm{~m}^{2} \mathrm{w}$ zależności od rodzaju paliwa oraz zapotrzebowania na ciepło. Available online: http://www.cena-pradu.pl/ogrzewanie.html (accessed on 16 June 2020). (In Polish).

37. Ustawa z dnia 29 września 1994 r. o rachunkowości (Dz.U. 1994 nr 121 poz. 591 z późn. zm.) Accounting Act of September 29, 1994. Available online: http://isap.sejm.gov.pl/isap.nsf/download.xsp/WDU19941210591/U/ D19940591Lj.pdf (accessed on 24 August 2020). (In Polish)

(C) 2020 by the authors. Licensee MDPI, Basel, Switzerland. This article is an open access article distributed under the terms and conditions of the Creative Commons Attribution (CC BY) license (http://creativecommons.org/licenses/by/4.0/). 